\title{
Introduction to the POMME special section: Thermocline ventilation and biogeochemical tracer distribution in the northeast Atlantic Ocean and impact of mesoscale dynamics
}

\author{
L. Mémery, ${ }^{1}$ G. Reverdin, ${ }^{2}$ J. Paillet, ${ }^{3}$ and A. Oschlies ${ }^{4}$ \\ Received 28 March 2005; revised 20 April 2005; accepted 4 May 2005; published 29 July 2005.
}

[1] Conducted in the northeast Atlantic Ocean $\left(15^{\circ} 20^{\prime}-21^{\circ} 20^{\prime} \mathrm{W}, 38^{\circ} \mathrm{N}-45^{\circ} \mathrm{N}\right)$, the Programme Océan Multidisciplinaire Méso Echelle (POMME) is a research project aimed at a better understanding of the biological production and the carbon budget of the region in relation to the formation mechanisms of the $11^{\circ}-12^{\circ} \mathrm{C}$ mode water of the northeast Atlantic. With the help of two research vessels, several tens of floats and drifters, and nine moorings, the field experiment was carried out between autumn 2000 and autumn 2001, with a more intensive phase in the winter and early spring of 2001. The field experiment resolved small (several kilometers) to regional (several hundred kilometers) scales and daily to seasonal variability. A first analysis of the rich data set focused on the large-scale and the mesoscale variability. It shows that the distribution of water mass characteristics and biological activity is strongly influenced by the mesoscales in this supposedly quiet transition zone between the subtropical and subpolar gyres. The seasonal variability, however, presents an imprint of the large-scale structures with a clear north-south gradient in properties and budgets. This region is found on an annual average to be a sink of atmospheric $\mathrm{CO}_{2}$. Smaller scales, associated with fronts and filaments, were clearly observed in many fields (temperature, but also chlorophyll, oxygen, biogenic particles, etc.), with modeling studies suggesting that they play a significant role in subduction, ventilation, and transport of biogeochemical tracers in the POMME region.

Citation: Mémery, L., G. Reverdin, J. Paillet, and A. Oschlies (2005), Introduction to the POMME special section: Thermocline ventilation and biogeochemical tracer distribution in the northeast Atlantic Ocean and impact of mesoscale dynamics, J. Geophys. Res., 110, C07S01, doi:10.1029/2005JC002976.

\section{Introduction}

[2] Programme Océan Multidisciplinaire Méso Echelle (POMME) is a study in the of subduction and Mode Water formation, as well as of processes responsible for the evolution of the biogeochemical properties of the modal water and for the export of biogenic matter over a seasonal cycle in the northeast Atlantic. The region selected is centered on $41.5^{\circ} \mathrm{N} / 19^{\circ} \mathrm{W}$ between the Iberian Peninsula and the Azores Islands and the field experiment was carried out in 2000-2001. According to the climatology, this region corresponds to a transition zone between relatively

\footnotetext{
${ }^{1}$ Laboratoire des Sciences de l'Environnement Marin, Institut Universitaire Européen de la Mer, Centre National de Recherche Scientifique/ Université Bretagne Occidentale, Plouzané, France.

${ }^{2}$ Laboratoire d'Océanographie et du Climat, Expérimentations et Approches Numériques, Institut Pierre-Simon Laplace, Centre National de Recherche Scientifique/Institut de Recherche pour le Développment/ Université Pierre et Marie Curie, Paris, France.

${ }^{3}$ Service Hydrologique et Océanographique de la Marine, Brest, France.

${ }^{4}$ School of Ocean and Earth Science, Southampton Oceanography Centre, University of Southampton, Southampton, U.K.
}

Copyright 2005 by the American Geophysical Union. 0148-0227/05/2005JC002976 deep late winter mixed layers in the north (reaching about $500 \mathrm{~m}$ ) and shallower winter mixed layers $(100-150 \mathrm{~m})$ in the south [de Boyer Montégut et al., 2004]. Subduction of the $11^{\circ}-12^{\circ} \mathrm{C}$ subpolar mode water of the northeast Atlantic is expected to take place across this mixed layer depth transition. Both hydrographic [McCartney, 1982; Paillet and Arhan, 1996; Paillet and Mercier, 1997] as well as drifter [Brügge, 1995] and float studies (ARCANE floats at $450 \mathrm{~m}$ ) typically suggest a net southward drift in this region, during which the late winter mode water gets subducted into the thermocline. On its subsequent path around the subtropical gyre, it influences the vertical stratification (low potential vorticity) equatorward to $28^{\circ} \mathrm{N}$. In apparent contrast to this first picture, there are other surveys (for instance, Vivaldi-1991 [Pollard et al., 1996; Cunningham, 2000]) which do not portray this meridional circulation and suggest an important contribution of the mesoscale features in the net meridional transport of the potential vorticity signal associated with this mode water [Leach et al., 2002]. How the imprint of the mode water is actually transmitted from the mixed layer structure into the thermocline and how it is transported meridionally remain therefore open questions. Another key issue is the impact of mesoscale dynamics on the net subduction rates of the mode waters [Weller et al., 
2004]. Until now, most of the studies undertaken to address these issues have been based on modeling approaches, and their conclusions are equivocal, with some of them showing a large [Hazeleger and Drijfhout, 2000; Valdivieso da Costa et al., 2005], moderate [Nurser and Zhang, 2000], or a rather weak [Spall et al., 2000] contribution of these medium scales to the ventilation of the thermocline.

[3] The study area is known to be a sink of atmospheric carbon [Takahashi et al., 1995] and to present a large export of primary production [Jickells et al., 1996]. The coupling of mesoscale physical and biological processes is one of the major objectives of the project. The winter mixed layer depth discontinuity zone is expected to divide the northeast Atlantic basin into two regions; a rather productive one, with a strong spring bloom to the north, associated with a deep winter mixed layer, and a more oligotrophic one to the south, with characteristics similar to those of the subtropical gyre [Wroblewski et al., 1988; Longhurst, 1993] (North Atlantic Bloom Experiment (NABE) [Ducklow and Harris, 1993]). Moreover, the onset of the spring bloom and the formation of mode waters are both related to the rapid retreat of the surface mixed layer in spring and accordingly were expected to occur during the same period. The exact timing of these processes plays, therefore, a major role in setting the characteristics of the water masses that, subsequent to subduction, may be isolated on a decadal timescale from the influence of the atmosphere. The export production associated with dissolved organic matter is also influenced by subduction. Finally, data have clearly shown that this area can be a strong sink of atmospheric $\mathrm{CO}_{2}$, mostly during the spring [Rios et al., 1992]. Both NABE and other in situ data [Lochte and Pfannkuche, 1987; Ducklow and Harris, 1993; Yoder et al., 1993; Karrasch et al., 1996] and modeling studies [McGillicuddy et al., 1995; Spall and Richards, 2000; Lévy et al., 2000; Oschlies and Garçon, 1998; Mahadevan et al., 2004] show that the highly nonlinear coupling between physical and biological activity at the mesoscale, and probably at submesoscale, is responsible for large variations in tracer distribution, $\mathrm{CO}_{2}$ air-sea fluxes and significantly impacts estimates of primary and export production, even on a basin scale.

[4] The objectives of POMME were the following.

[5] 1. Estimate the distribution of the late winter mixed layer depth and the associated biogeochemical properties of the mixed layer. How is the spatiotemporal evolution of the mixed layer shaped by the air-sea buoyancy fluxes and the mesoscale circulation and vorticity field?

[6] 2. Estimate the horizontal and vertical transports of buoyancy, potential vorticity, mass, heat, salt, nutrients, carbon. Quantify the contribution of the mesoscale circulation to those fluxes. What are the relevant coherent structures within the mesoscale field, and how do they contribute to the fluxes?

[7] 3. Investigate the spatiotemporal coupling between restratification at the end of winter, thermocline ventilation and associated water mass formation, and the spring bloom.

[8] 4. Describe the physical and biological processes responsible for the export of organic matter and of biogeochemical tracers to the thermocline (initial conditions and outcome), mostly nutrients, oxygen and $\mathrm{CO}_{2}$. Quantify the export of particulate and dissolved organic matter to the deep ocean.
[9] 5. Quantify the physical and biological processes involved in the bacterial and heterotrophic loops, which regulate the transformation of particulate and dissolved organic matter and hence the evolution of biogeochemical tracers in the subducted mode waters.

[10] The present paper will not attempt a thorough examination of these topics. It presents the implementation of the intensive study period in 2001, synthesizes early results depicted in the different papers of this special POMME issue, and provides some complementary information obtained through work currently in progress.

\section{Implementation of the Experiment}

[11] The core domain of the field experiment is a $500 \mathrm{~km}$ longitude by $750 \mathrm{~km}$ latitude area centered at $41^{\circ} 30^{\prime} \mathrm{N}$, $19^{\circ} \mathrm{W}\left(15^{\circ} 20^{\prime}-21^{\circ} 20^{\prime} \mathrm{W}, 38^{\circ}-45^{\circ} \mathrm{N}\right.$ (see Figure 1$)$ ). The field experiment took place mostly during a 1 year period starting in autumn 2000. There was an earlier limited hydrological survey in the spring 2000, and some instrumentation was left in place after October 2001 (three sediment trap/current meter moorings until June 2002, as well as some floats). Most of the data collection and processing were designed for delayed mode analysis, although some (physical) data were analyzed in real time in order to contribute to the logistical planning of the experiment (in particular during cruises).

\subsection{Phasing}

[12] Cruises were carried out in different seasons over the 1 year period (Table 1) to deploy or recover equipment, to carry out surveys (physical and biogeochemical) and to maintain four time series stations. The survey arrays were at a mesoscale resolution (typically $55 \mathrm{~km}$ ) or at a higher resolution. The 2 day time series stations were carried out while following a drifting sediment trap with the aim to investigate biogeochemical processes in a Lagrangian onedimensional framework. The cruises (P0, P1, P2 and P3 (see Table 1)) varied in duration and scope, with the two most extensive cruises (P1 and P2) carried out from February through early May 2001 in order to investigate both late winter and early spring situations. The cruises typically involved two vessels. P1 to P3 had two legs with a total duration of over 50 days each (more than 40 days within the POMME domain). The two vessels could gather physical measurements and collected samples for later analyses, but only one of the two vessels (R/V Atalante for P1 and $\mathrm{P} 2, \mathrm{R} / \mathrm{V}$ Thalassa for $\mathrm{P} 0$ and $\mathrm{P} 3$ ) was instrumented for carrying out specific biogeochemical investigations. Usually, the first leg of the cruise was dedicated to mesoscale surveys while the second leg was dedicated to higher-resolution surveys of specific structures and time series stations (Figure 2). Real-time data analysis and model simulations were used to optimize the sea operations, in particular to locate specific structures during the second legs.

\subsection{Deployed Instrumentation}

[13] Specific instrumentation was deployed for the following.

[14] 1. Estimate the air-sea fluxes: a meteorological mooring for collecting bulk measurements and radiative flux measurements from 26 August 2000 to 5 May 2001; an 


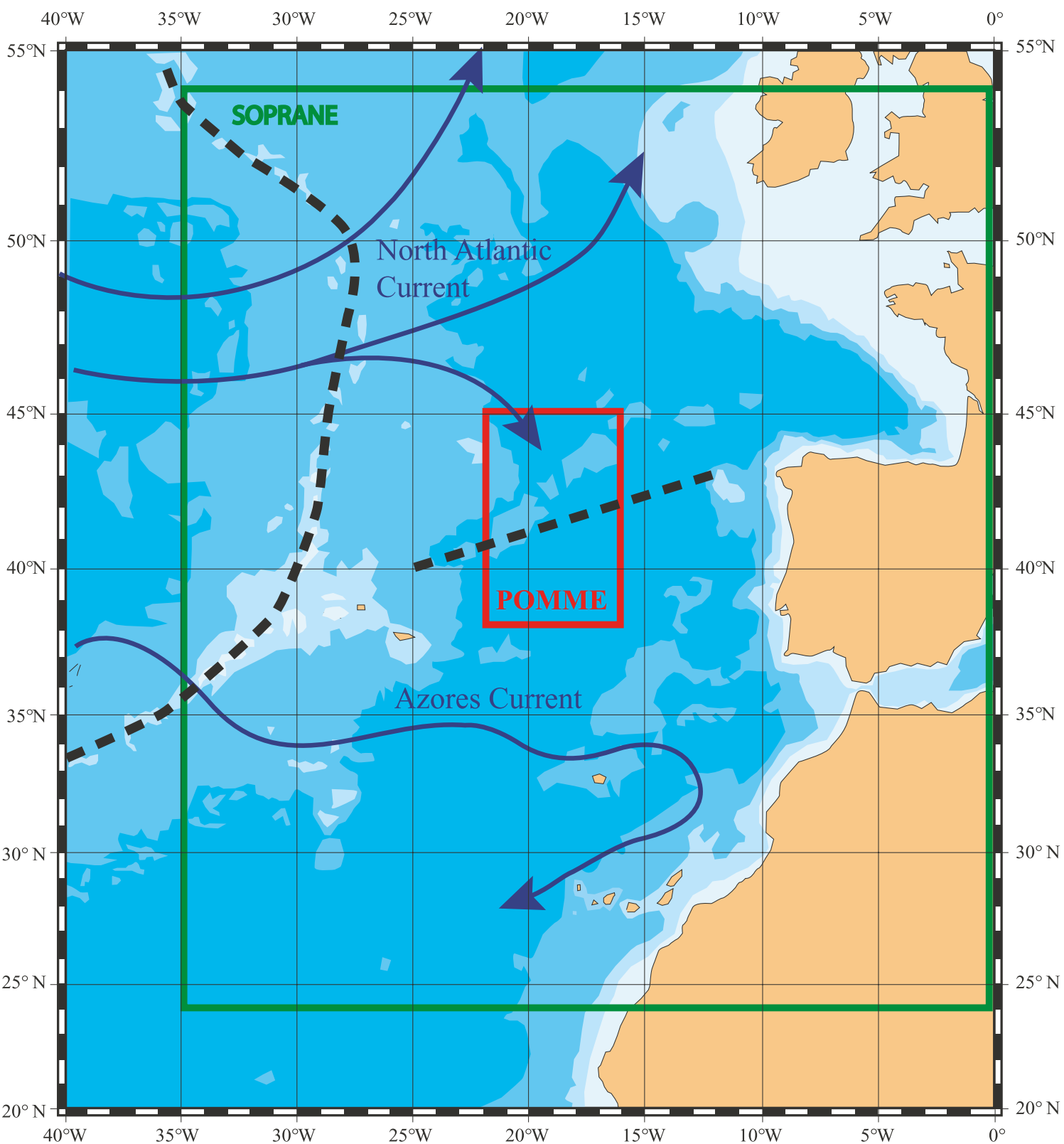

Figure 1. Programme Océan Multidisciplinaire Méso Echelle (POMME) region. The red square is the area of intensive in situ survey during the POMME program in 2001. The green square is the region simulated by the QG Système Océanique de Prévision Régionale en Atlantique Nord Est (SOPRANE) model, used in quasi-real-time assimilation mode during the POMME cruises. The dashed bold line is the approximate location of the zone of discontinuity of the winter mixed layer, associated with subduction of mode water masses.

instrumented mast was operated on the February through May 2001 R/V Atalante cruises to estimate air-sea momentum, heat and freshwater fluxes; 24 drifters with wind speed measurement devices were deployed, mostly in February; four CARIOCA drifters were deployed in February 2001 to measure the air-sea carbon dioxide fluxes (with $\mathrm{pCO}_{2}$, wind speed, fluorescence, T, S measurements, with additional $\mathrm{pH}$ measurements on one drifter).

[15] 2. Measure the circulation: nine current meter moorings, including three with upward looking ADCP in the surface layer associated with thermistor chains (emphasis was on the currents near $400 \mathrm{~m}$ or above), almost 100 floats of different types drifting mostly at subsurface levels shallower than $400 \mathrm{~m}$ (half of which were tracked acoustically, whereas some were PALACE-type profiling floats located only during regular surfacing intervals, and some floats had a drogue tethered to a surface element to provide hourly localization via GPS); surface drifters, also of different types, of which only a subset (19) were circulation drifters drogued at $15 \mathrm{~m}$ as designed for WOCE [Niiler et al., 1995], the others being drogued insufficiently or not at all and designed often for other purposes (including 20 
Table 1. Dates of Cruises and Names of Ships

\begin{tabular}{|c|c|c|}
\hline Cruise & Vessels & Period \\
\hline P0 & Thalassa ${ }^{\mathrm{a}}$ & 17 Sep $2000-14$ Oct 2000 \\
\hline \multicolumn{3}{|l|}{ P1 } \\
\hline Leg 1 & Atalante, ${ }^{\mathrm{a}} D^{\prime}$ Entrecasteaux & 3 Feb 2001-27 Feb 2001 \\
\hline Leg 2 & Atalante, ${ }^{\mathrm{a}} D^{\prime}$ Entrecasteaux ${ }^{\mathrm{b}}$ & 24 Mar 2001-14 Apr 2001 \\
\hline \multicolumn{3}{|c|}{ 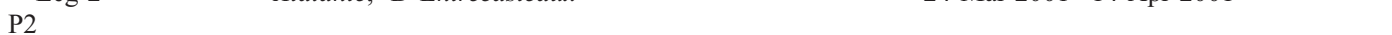 } \\
\hline Leg 1 & Atalante, ${ }^{\mathrm{a}} D^{\prime}$ Entrecasteaux ${ }^{\mathrm{b}}$ & 24 Mar 2001-14 Apr 2001 \\
\hline Leg 2 & Atalante, ${ }^{\mathrm{a}} D^{\prime}$ Entrecasteaux ${ }^{\mathrm{b}}$ & 16 Apr $2001-16$ May 2001 \\
\hline \multicolumn{3}{|r|}{10 Арі $2001-10$ Niay 2001} \\
\hline Leg 1 & Thalassa ${ }^{\mathrm{a}}{ }_{\text {BSHM Ailette }}^{\mathrm{b}}$ & 23 Aug 2001-14 Sep 2001, 30 Aug 2001-14 Sep 2001 \\
\hline Leg 2 & Thalassa ${ }^{\mathrm{a}}{ }_{\text {BSHM Ailette }}^{\mathrm{b}}$ & 17 Sep $2001-11$ Oct 2001,17 Sep $2001-29$ Sep 2001 \\
\hline
\end{tabular}

MARISONDE and 4 CARIOCA drifters, as well as floats having lost their drogues or having drifted in this area from other regions of the Atlantic Ocean). Most of these drifters and floats measured water temperature and eight of the surface drifters also measured salinity (only the four CARIOCA drifters measured it with good results).

[16] 3. Measure the near surface/upper water column stratification during the late winter-early spring period, either from thermistor chains associated to the three ADCP moorings, from 20 surface drifters with thermistor chains (MARISONDE), or from PALACE-type floats.
[17] 4. Estimate the vertical particle fluxes with four sediment trap moorings (with traps at levels roughly near 400 and $1000 \mathrm{~m}$ ) with 10 day collection time intervals from February to September 2001; three of the sites were reequipped from September 2001 to June 2002 with 15 day collection time intervals.

\subsection{First Legs of the Cruises}

[18] Mesoscale arrays of 30NM (55 km) nominal resolution were completed during the first legs, with two ships (Figure 2 (left)). The individual stations included conduc-
Leg 1

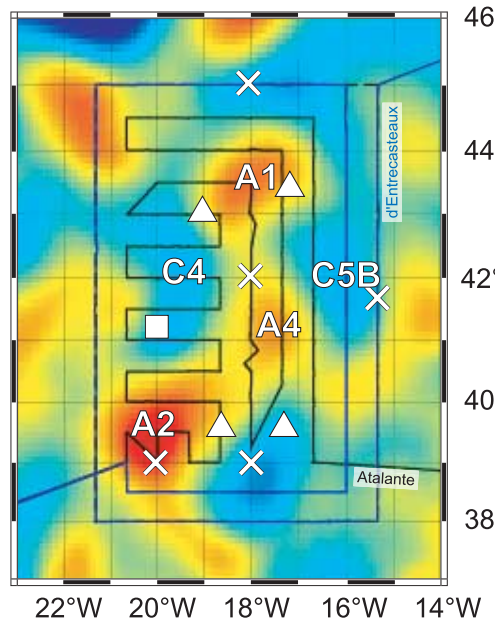

\section{Leg 2}

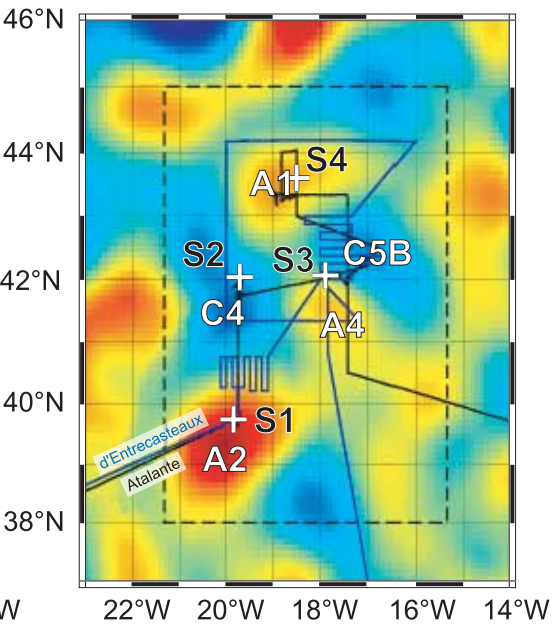

Figure 2. Coverage of a typical POMME cruise (P2) with two oceanographic vessels: the black line is the Institut Français de Recherche pour l'Exploitation de la Mer (IFREMER) vessel (here Atalante); the blue line is the Service Hydrologique et Océanographique de la Marine (SHOM) vessel (d'Entrecasteaux). The maps show the stream functions resulting from SOPRANE (QG model) simulations using altimetry data assimilation. The red (blue) color is associated with anticyclonic (A) (cyclonic (C)) circulations. The major structures are shown by a name indicated in white. (left) Hydrological survey with a spacing between stations of 30 NM (Figure 3). White triangles are sediment trap moorings, white crosses are current meter moorings, and the white square is a meteorological mooring. (right) The IFREMER vessel carried out four time series quasi-Lagrangian stations (white crosses, named S1-S4), and Tow-Yo high-resolution sections in between, across frontal structures or a few eddies. The SHOM vessel was dedicated to Seasoar/Optical Plankton Counter Towed (OPCT) sections, mostly as radiators resolving specific patterns, like fronts (around $20^{\circ} \mathrm{W}, 40^{\circ} \mathrm{N}$ ) or saddle points between eddies (around $18^{\circ} \mathrm{W}, 42.5^{\circ} \mathrm{N}$ ). The position of these high-resolution sections or radiators was decided using information obtained from reanalysis of SOPRANE simulations, taking into account in situ (conductivity-temperature-depth (CTD)) data of the first leg (Figure 3). The date of the SOPRANE results corresponds approximately to the middle of the leg. 
tivity-temperature-depth (CTD) casts, commonly to $2000 \mathrm{~m}$, and occasionally to the bottom, generally associated with LADCP current profiles. For the casts of the first leg, samples were collected from 21 depth levels $(\mathrm{R} / \mathrm{V}$ Atalante/Thalassa) or 12 levels (N/O d'Entrecastaux), respectively, most of them located in the upper $400 \mathrm{~m}(\mathrm{R} / \mathrm{V}$ Atalante/Thalassa). These samples were used to measure a set of core parameters: nutrients (the most complete set during $\mathrm{P} 1, \mathrm{P} 2 \mathrm{P} 3$ on $\mathrm{R} / \mathrm{V}$ Atalante/Thalassa), $\mathrm{O}_{2}, \mathrm{DIC}$, DOC, chlorophyll, pigments, DMS-P/DMS, bacterial biomass, but also samples for flow cytometry (picoplankton), phytoplankton taxonomy, primary production, bacterial production, and net community production, various kinetic experiments, quality of the organic matter, grazing and degradation experiments, and particle loading (HIAC). At roughly half of the stations, a CTD equipped with a fairly complete set of bio-optical instruments was lowered to a depth of $500 \mathrm{~m}$. At the other stations, a marine camera equipped for identification of large particles and zooplankton was lowered to $1000 \mathrm{~m}$. During the transits, acoustic Doppler current profile (ADCP) measurements were collected (R/V Atalante/Thalassa and N/O d'Entrecastaux) and $\mathrm{T}, \mathrm{S}, \mathrm{DMS}, \mathrm{PCO}_{2}$ and bio-optical properties of the surface water (HIAC, AC9, fluorescence) were continuously recorded on the R/V Atalante/Thalassa (P1, P2 and P3).

[19] Physical measurements were analyzed in near real time and combined with stream functions of the Système Océanique de Prévision Régionale en Atlantique Nord Est (SOPRANE) operational model run by Service Hydrologique et Océanographique de la Marine (SHOM) [Assenbaum and Reverdin, 2005] to provide chief scientists with the best possible estimate of the dynamical situation. That situation was thoroughly studied during and after the first legs to decide on the sampling strategy of the second legs.

\subsection{Second Legs of the Cruises}

[20] The high-resolution surveys during the second legs employed a CTD equipped with additional sensors for $\mathrm{O}_{2}$, fluorescence and other optical properties in a Tow-Yo mode along sections on the R/V Atalante/Thalassa (P2 and P3) and with a Seasoar/Optical Plankton Counter Towed (OPCT) towed by the d'Entrecastaux during P2 (two surveys sampled as radiators (Figure 2 (right))). During the first leg of P3, the second vessel was only available for a reduced time and performed high-resolution sections towing a Seasoar/OPCT set of instruments. In general, the highresolution surveys of $\mathrm{P} 1, \mathrm{P} 2, \mathrm{P} 3$ focused on structures in the central part of the domain (e.g., the front at $41^{\circ} \mathrm{N}$, the anticyclone A1, a section from anticyclone A2 to cyclone C4 (see Figure 2)). The analysis of these data is still under way.

[21] The Lagrangian time series stations were carried out by the Atalante/Thalassa to investigate biogeochemical processes in an approximate one-dimensional (1-D) framework (Figure 3). Usually, they lasted for up to 2 days, with some of the experiments being shorter due to weather or ship time constraints. A drifting buoy equipped with two subsurface sediment traps (at $200 \mathrm{~m}$ and $400 \mathrm{~m}$ ) was deployed during the stations to provide a quasi-Lagrangian reference position. Water samples collected at regular hydrographic stations during the drift allowed to study the evolution of the biogeochemical system (phytoplankton taxonomy, nutrients, oxygen, pigments, dissolved and particular, organic and inorganic carbon), and water collected with the in situ pump allowed for iron and other chemical tracer studies as well as for experiments on the dissolved and particulate organic matter). Specific net tows were carried out at regular intervals for investigating the mesozooplankton (WP2 nets for sampling vertically integrated zooplankton from either 200 or $400 \mathrm{~m}$ up to the surface with a size ranging from $250 \mu \mathrm{m}$ to $2 \mathrm{~mm}$ and multiple net BIONESS able to sample nine different depths down to $700 \mathrm{~m}$ in the size range of $550 \mu \mathrm{m}$ to $5 \mathrm{~cm}$ appropriate to sample large copepods, macroplankton and micronekton). Primary production and bacterial production were measured in situ, and in situ experiments for net carbon and oxygen balances were conducted as well.

\subsection{General Observations}

[22] The data return from the instruments deployed was usually good, and the data provide good information on the mesoscale circulation during September 2000-2001, as well as on the air-sea exchange of heat, fresh water, and $\mathrm{CO}_{2}$ at least until May 2001 and on changes in the upper ocean stratification between late winter to summer 2001 . The mesoscale surveys were completed almost as scheduled (the worst one is P1 with $95 \%$ of the stations occupied). However, because of time constraints, not all the variables could be sampled and analyzed for all individual levels or stations. During the second legs of the cruises, most of the time series stations could be occupied with one cut short during both P1 and P3. There were fewer high-resolution surveys/sections than planned, for P1 and P3, whereas the leg 2 of P2 was accomplished as foreseen.

[23] As expected, the duration of the mesoscale surveys (21 days) was long compared to the characteristic timescales of the ecosystems, of the biogochemistry, and spring time changes in the mixed layer depths. There was also substantial evolution of the mesoscale field during the surveys. This results in nonsynopticity that needs to be kept in mind when constructing and interpreting maps and comparing areas of individual surveys, in particular during the period associated with the spring restratification and bloom (P2). There was also significant exchange of water between the POMME domain and neighboring areas of the Atlantic, in particular between $\mathrm{P} 0$ and $\mathrm{P} 1$ or $\mathrm{P} 2$ and $\mathrm{P} 3$.

\section{Preliminary Results}

\subsection{Physical Oceanography}

\subsubsection{Air-Sea Fluxes}

[24] Because of the effort spent on in situ instrumentation, night/morning SST could be mapped at mesoscale resolution during the whole experiment on a 3 daily resolution despite an often rather poor coverage in satellite SST data [Caniaux et al., 2005a]. Estimates of the air-sea fluxes were produced from various sources (in situ, satellite, weather forecast models) and a mapped product combining this information was produced [Caniaux et al., 2005a]. The air-sea fluxes were strongly influenced by the mesoscale 


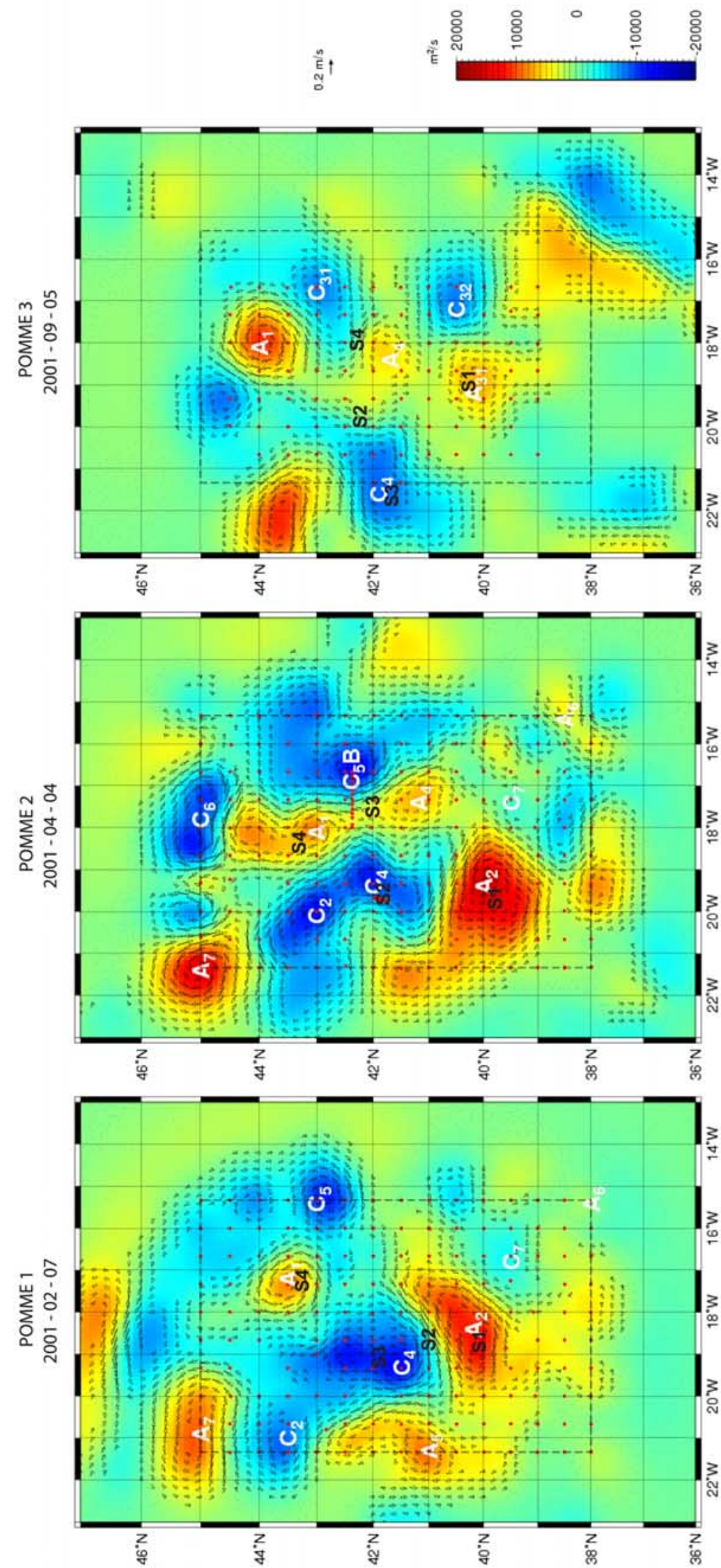

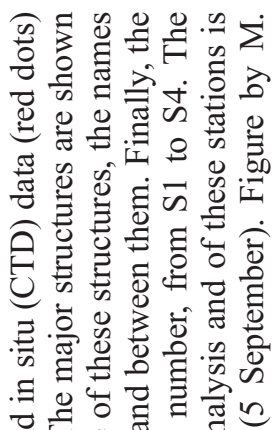
击

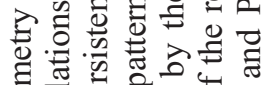

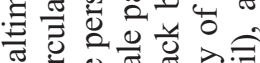

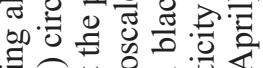

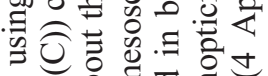

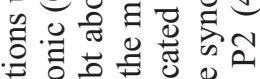

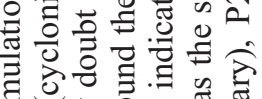

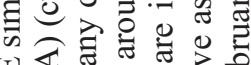

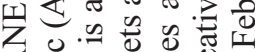

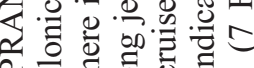

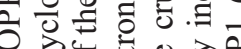
次它纯

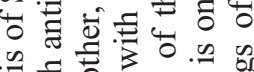

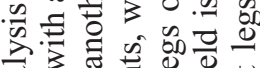

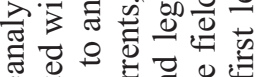

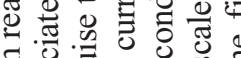
등 웡 \& on o

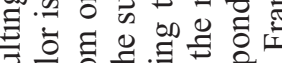

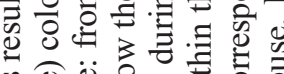

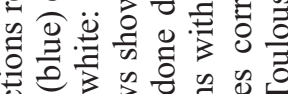
린

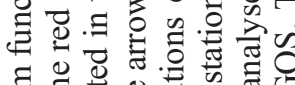

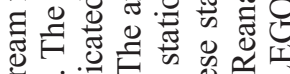
os 0

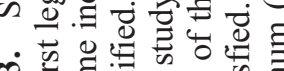

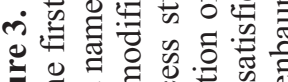

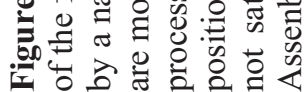


features in the SST field which modulate the low-level winds [Bourras et al., 2004]. A careful analysis of the upper ocean temperature/salinity evolution between successive surveys suggests that these initial flux estimates were biased. Attempts to correct heat and freshwater fluxes were conducted in order to minimize large-scale discrepancies [Caniaux et al., 2005b]. Ocean circulation models using these corrected fluxes reproduce the large-scale evolution of mixed layer depth very well (at least in late winter/spring). These corrected fluxes indicate a change after 10 March 2001, in a large part of the domain, from a situation with a net buoyancy loss to a net buoyancy gain of the ocean. The buoyancy gain further intensifies by mid-May. The day-to-day variability associated with weather systems is relatively large, but with a tendency for fairly long-lasting weather regimes with a dominance of southwesterly or northeasterly winds over most of the domain during the period February through May. The annually averaged heat and fresh water fluxes are suggestive of a slight buoyancy loss of the ocean which partially contributes to a net increase of the upper ocean heat content in this region during September 2000 to September 2001.

\subsubsection{Circulation}

[25] The POMME observational period turned out to be a year with above average kinetic eddy energy north of $40^{\circ} \mathrm{N}$ based on the 1993-2002 time series of satellite altimetry, while the region remains less active than areas further north or in the vicinity of the Azores Current. The ocean circulation associated with this eddy distribution was strongly variable, with a meridional gradient of activity largest near $44^{\circ}-45^{\circ} \mathrm{N}$ and $41^{\circ} \mathrm{N}$ [Assenbaum and Reverdin, 2005; Gaillard et al., 2005; Le Cann et al., 2005]. In particular, these analyses show a quasi-permanent eastward current in the upper $500 \mathrm{~m}$ usually centered near $41.5^{\circ} \mathrm{N}$ at least until June 2001 with maximum velocities in the core exceeding $30 \mathrm{~cm} \mathrm{~s}^{-1}$, but at individual times presenting large meanders around various eddy structures. This is also often a boundary in upper ocean water masses [Reverdin et al., 2005], although between the surveys there was also a large evolution of the northeast Atlantic mode water south of this boundary, suggesting some seepage of water with more northern properties. This water transited probably along the eastward current near $41^{\circ} \mathrm{N}$ with a connection to regions farther north to the west of the POMME domain. North of this current and south of a branch of the North Atlantic Current located to the north of the POMME area, the circulation is strongly influenced by mesoscale features (Figure 3), which still leave their signature in the annually averaged currents. The dispersion of the floats is clearly larger in this region with higher eddy energy than in the less energetic southern part of the domain. Some long-lasting coherent structures, in particular anticyclones, were identified [Le Cann et al., 2005], with their coherent cores probably covering up to $5 \%$ of the domain surface. Most of them drifted westward or southwestward, although with a high variability of drift from structure to structure and in time. The anticyclonic eddy A1 (Figure 3) was particularly well followed by floats for a year, and often at more than one level in the vertical. After drifting southwestward through March 2001, it remained almost stationary until the end of the experiment in September 2001. The data, both from these floats and during the cruises indicate that this eddy typical of swoddies [Pingree and Le Cann, 1992] has a small coherent core with a radius on the order of $30 \mathrm{~km}$ and maximum velocity near $300-400 \mathrm{~m}$ decreasing quickly toward the surface and $1000 \mathrm{~m}$. The central part of the structure contained a fairly dense kind of mode water not characteristic of mode water formed within the POMME domain's immediate vicinity. Also, some floats were trapped in smaller cyclonic eddies entrained in strong currents near the rim of these cyclonic zones.

\subsubsection{Mixed Layer}

[26] Not surprisingly, at each location, the mixed layer depth during late winter was found to be highly variable due to day-to-day changes in the air-sea heat fluxes. In addition, time integrations of a diagnostic regional model guided along specified geostrophic ocean currents [Giordani et al., 2005] and of carefully initialized regional three-dimensional ocean models [Paci et al., 2005] indicate that the deepest mixed layers in 2001 were also highly variable spatially with an indication of deep mixed layer $(>300 \mathrm{~m})$ reached in the northwest corner (within the anticyclonic eddy A7-A8), and also near the northeastern boundary of the domain. Densest winter mixed layer waters were found in the later area (near $1027.10 \mathrm{~kg} \mathrm{~m}^{-3}$ ), whereas the highest surface density in the northwest was closer to $1026.95 \mathrm{~kg} \mathrm{~m}^{-3}$ [Reverdin et al., 2005]. Elsewhere in the domain, these model results suggest a large spatial variability in the mixed layer depth related both to the forcing (heat fluxes) and to the ocean circulation (eddies, but also submesoscale features), with deepest values often around 150-250 m. The deepest mixed layers were often reached close to 6 March, but with a high spatial variability too, with dates as late as 15 April or later in A7 in the northwest corner. Averaged over the POMME domain, and in comparison with other simulated years, the period of study during POMME can be characterized by a year with a fairly gradual retreat of mixed layer depth from mid-March through early May [Lévy et al., 2005a]. This implies that during the first leg of P2, most of the southwest part of the POMME domain that was sampled near the end of the cruise had already witnessed a long period of surface mixed layers being shallower than the euphotic zone (approximately the uppermost $120 \mathrm{~m}$ ).

[27] On the basis of the observed stratification and oxygen fields as well as on the estimated circulation, newly formed mode water found in the eastern part of the POMME domain in 2001 with density 1027.10$1027.15 \mathrm{~kg} \mathrm{~m}^{-3}$ originated probably from somewhere close to the northeast boundary of the POMME domain. Near the northwest corner, a weakly stratified layer forms at a density of about $1026.95 \mathrm{~kg} \mathrm{~m}^{-3}$ in spring. Other water masses formed in the POMME area in spring 2001 showed generally higher stratification, and little of these waters seem to have reached the southern part of the POMME domain by September 2001 [Reverdin et al., 2005]. Precise subduction rates on an annual basis cannot be estimated at this point, as large exchanges with the outside of the domain took place between P2 and P3. In addition, strong vertical mixing events may also contribute to the changes in stratification. A detailed analysis of the data at one mooring $(\mathrm{N})$ at 


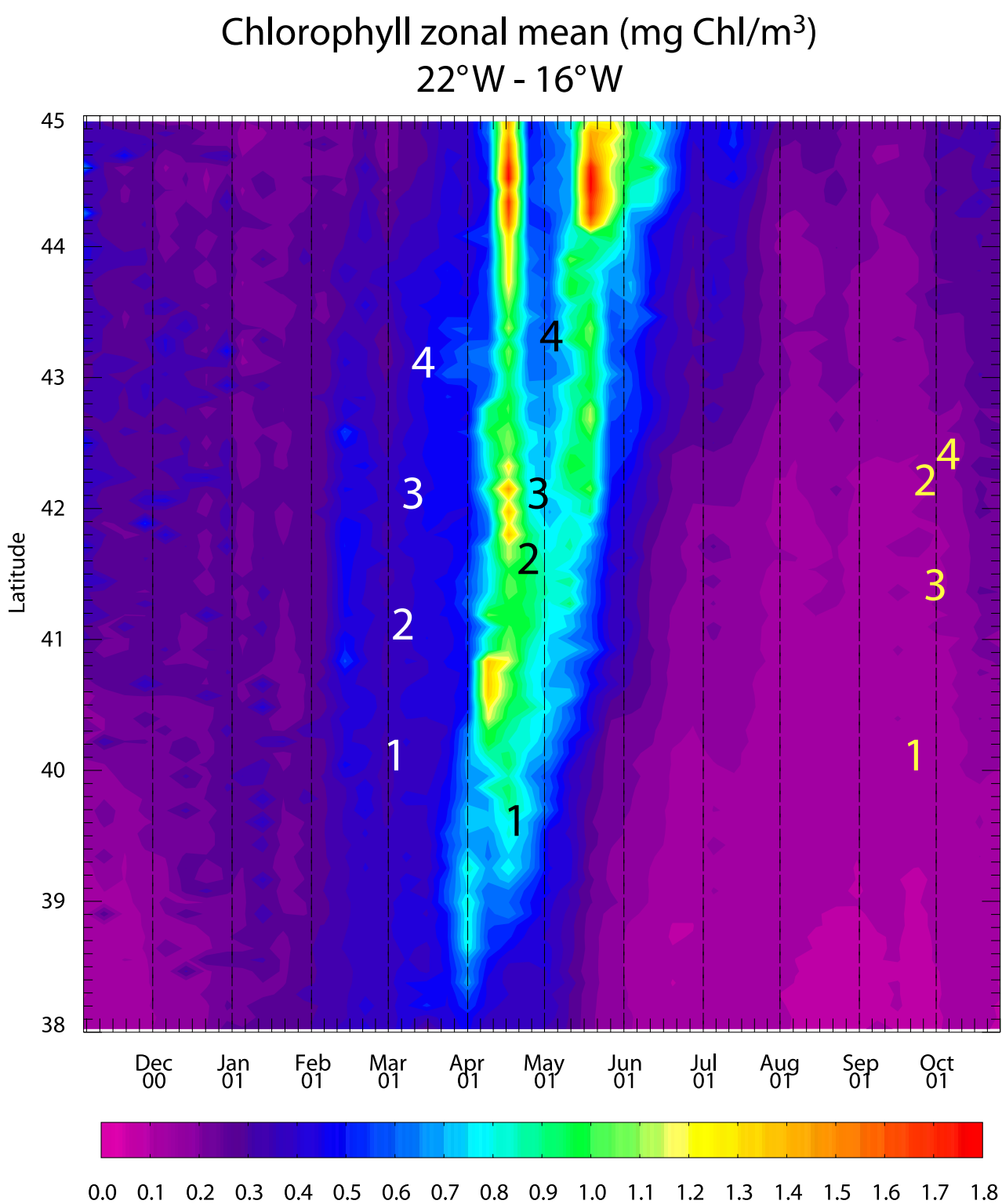

Figure 4. Annual evolution of the zonal average of Sea-viewing Wide Field-of-view Sensor (SeaWiFS) chlorophyll against latitude in the POMME area. The numbers indicate the location of time and latitude of the process study stations of the second legs (white, P1; black, P2; yellow, P3). North of $42^{\circ} \mathrm{N}$, the bloom has been "stopped" at the end of April for several weeks, and the end of P2 occurred during that period. Figure by Y. Lehahn and M. Lévy (LODYC, Paris).

$18^{\circ} \mathrm{W}, 45^{\circ} \mathrm{N}$ indicates mixing events associated with propagating internal waves, possibly related to wind and tidal forcing [Bouruet-Aubertot et al., 2005]. Analysis of its impact on the evolution of the stratification remains to be done.

\subsection{Biological Cycles}

\subsubsection{Seasonal Variability}

[28] SeaWiFS images (Figure 4) show that the first leg of P1 took place at a time when zonal average surface chlorophyll concentrations were low $\left(0.3 \mathrm{mgChl} \mathrm{m}^{-3}\right)$, with concentrations even lower during P3 (less than $0.1 \mathrm{mgChl} \mathrm{m}^{-3}$ ). In contrast, during the first leg of $\mathrm{P} 2$, surface chlorophyll was higher ( $1 \mathrm{mgChl} \mathrm{m}^{-3}$ and more), but the satellite images show that north of $42^{\circ} \mathrm{N}$ the bloom was interrupted for about 2 weeks during the second leg of P2. The sites 3 and 4 were sampled during this period of relatively low average activity [Lévy et al., 2005a].

[29] Observed nitrate and phosphate distributions suggest that, at least in the southwest, nutrient uptake had already begun before cruise P1 (beginning of February), whereas, in agreement with the satellite data, the bloom was not over yet north of the $41^{\circ} \mathrm{N}$ front at the beginning of May (end of P2) [Fernández et al., 2005a]. During cruise P3, nutrients were depleted at the ocean surface: the system was strongly oligotrophic. This seasonal evolution is also observed in the rates of biological production and in variations in the phytoplankton taxonomy. 
[30] An increase of primary production (PP) is observed between $\mathrm{P} 1$ and P2 (almost by a factor of 3 from $456 \mathrm{mgC} \mathrm{m}^{-2} \mathrm{~d}^{-1}$ during the first leg of P1 (February) compared to $1236 \mathrm{mgC} \mathrm{m}^{-2} \mathrm{~d}^{-1}$ during the first leg of $\mathrm{P} 2$ (April) [Fernández et al., 2005b]). It is related to the receding mixed layer and an increase in near surface phytoplankton biomass, but is not as strong as one could expect from the large change in mixed layer depth between the two cruises. During P3 (September), the PP values were close to the winter estimates (420 $\mathrm{mgC} \mathrm{m} \mathrm{m}^{-2} \mathrm{~d}^{-1}$ ). In general, the contribution of nanophytoplankton to PP is largest, although during the strongly oligotrophic period sampled during P3, it is exceed that of picophytoplankton (about 50\% [Claustre et al., 2005]). Even during P2, the contribution of picophytoplankton does not dominate PP (around 30\% for cells larger than $10 \mu \mathrm{m}$ ). This is consistent with results from plankton taxonomy which indicate that the diatoms that provide a large contribution to the biomass during P2 (Pseudo nitzchia spp) are often relatively small; e.g., part of the nanophytoplankton production could originate from small diatoms [Leblanc et al., 2005]. This unexpected phenomenon may result from silicate being a limiting element which is suggested by the incubation experiments performed to estimate the half saturation constant of silicate uptake during P2 but also during P1 [Leblanc et al., 2005]. Incubation experiments also indicate that iron is limiting, although episodic deposition of dust of Saharan origin might relieve this limitation [Blain et al., 2004]. The iron limiting effect is larger in winter, and could together with other colimitations decrease the uptake rates of carbon by $70 \%$. This result contrasted with the expectation that the POMME region in the NE Atlantic Ocean is not an HLNC region.

[31] At the end of P2, and mostly during P3, macronutrients also limit the production: the molar nitrogen/ phosphate ratio decreases down to 5 at the surface (T. Moutin, personal communication, 2004), the diatom concentrations and biogenic silicate production are extremely low [Leblanc et al., 2005], and the few large cells which can be observed within some mesoscale structures are dinoflagellates (HPLC data [Claustre et al., 2005]). The distribution of species results in a low $F$ ratio $\left(\mathrm{NO}_{3}\right.$ uptake/ $\mathrm{NH}_{4}$ uptake). Moreover, as nitrification rates are strong (between 5 and up to more than $50 \%$ of nitrate uptake), part of the nitrate uptake is in fact regenerated production, even in winter [Fernández et al., 2005a], and the corrected $F$ ratio estimates are on the order of 0.5 during P1 and P2 (and 0.2 during P3 [Fernández et al., 2005b]).

[32] Cruise to cruise differences in bacterial production (BP) tend to mimic those of primary production, but the $\mathrm{BP} / \mathrm{PP}$ ratio increases with time (from $10 \%$ during $\mathrm{P} 1$ and P2 up to $28 \%$ during P3 (F. Van Wambeke, personal communication, 2004)). This increase goes along with an increase in the Bacterial Growth Efficiency (BGE), from $8 \%$ during $\mathrm{P} 1$ and $14 \%$ during $\mathrm{P} 2$ to $24 \%$ during $\mathrm{P} 3$. The major part of this BP is consumed by heterotrophic nanoflagellates [Karayanni et al., 2005]. Grazing pressure exerted by these small heterotrophs, and by ciliates is equivalent to about $30 \%$ of the daily primary production, but it can reach more than $80 \%$ per day on some occasions (F. Van Wambeke, personal communication, 2004). Given a refractory background DOC concentration of around $41 \mathrm{mmolC} \mathrm{m}{ }^{-3}$, the POMME area is characterized by an accumulation of semilabile DOC of up to $15 \%$ of the background value during P3.This semilabile pool can potentially be exported into the permanent thermocline during spring subduction, after deep winter mixing [Sohrin and Sempéré, 2005].

[33] The zooplankton community shows a very pronounced seasonal variability, in terms of species, functional impact, grazing pressure and remineralization fluxes. The Bioness results show that the average macroplankton biomass in the $0-700 \mathrm{~m}$ depth range is 4 (3) times higher during P2 (P3) than during P1 (V. Andersen, personal communication, 2003). Moreover, in terms of numbers, omnivorous species are mostly predominant during P2, whereas carnivorous species dominate during P3. Significant stocks of herbivorous species are found in the north during P1 and in the south during P2. Large copepods, as well as euphausiids, are mostly present in April, during P2, whereas the copepod concentrations are very low in September and those of euphausiids are low in February. The WP2 biomass results present a high variability and somewhat conflicting results (V. Andersen, personal communication, 2003). One set of hauls indicated somewhat higher biomass during the fall cruise $\left(2.6 \mathrm{~g} . \mathrm{m}^{-2}\right)$, while the other set suggested a spring maximum of mesozooplankton biomass. This contradiction can be resolved with an integrated view of the area possible by the OPC transects, which showed that biomass varied from $4 \mathrm{~g} \mathrm{~m}^{-2}$ in spring to $2.5 \mathrm{~g} \mathrm{~m}^{-2}$ in fall. An earlier study in the same sampling zone in 2000 yielded similar spring biomass estimates. In term of carbon, the WP2 data of P2 give an average of $3.4 \mathrm{mgC} \mathrm{m}^{-3}$ (between 0.7 and $7.7 \mathrm{mgC} \mathrm{m}^{-3}$ ) over the $0-200 \mathrm{~m}$ depth range. This is comparable to the results obtained by Dam et al. [1993] during NABE during the same period (average of $4.4 \mathrm{mgC} \mathrm{m}^{-3}$ with variations from 2.1 to $6.1 \mathrm{mgC} \mathrm{m}^{-3}$ ): although the sampling during NABE was restricted to the mixed layer (shoaling from $120 \mathrm{~m}$ at the beginning (end of April) to $30 \mathrm{~m}$ at the end (end of May)), the range of biomass measurements is comparable between the two surveys. Another major observation during POMME was the large number of gelatinous species (pteropods and salps) during P2, and also to a smaller extent during P3. The grazing pressure on phytoplankton averaged over the top $200 \mathrm{~m}$ was higher during P2 (around $30 \%$ of the PP), and much lower during P1 (10\% of the PP) and P3 (25\% of a much smaller PP). During P2, the remineralization rates can be quite high and vary between 8 and $26 \mathrm{mmoleCO}_{2} \mathrm{~m}^{-2} \mathrm{~d}^{-1}$, or around $25 \%$ of the PP (P. Mayzaud, personal communication, 2004): these estimates have still to be made for the other cruises.

[34] The data return from the sediment traps is good (90\%): only one trap at $400 \mathrm{~m}$ did not collect during 2 months. The moorings display a clear seasonal cycle, with a maximum particle flux in March-April 2001, and 1 month later in 2002 [Guieu et al., 2005]: the interannual variability is strong, with higher particulate matter fluxes during the bloom in 2001 than in 2002 (at $400 \mathrm{~m}$, largest average fluxes over 10 days reaching $500 \mathrm{mg} \mathrm{m}^{-2} \mathrm{~d}^{-1}$ 
during March 2001 compared to $350 \mathrm{mg} \mathrm{m}^{-2} \mathrm{~d}^{-1}$ in AprilJune 2002). Data have been corrected using Thorium measurements: the efficiency of the sediment traps is rather low and highly variable varying from 18 to $55 \%$ (with the smallest value for the northeast mooring associated with high horizontal velocities, resulting certainly from the presence of the quasi permanent A1 structure nearby). A first estimate of particulate carbon export at $400 \mathrm{~m}$ during 2001 gives $5.2 \mathrm{mgC} \mathrm{m}^{-2} \mathrm{~d}^{-1}$ and $4.9 \mathrm{mgC} \mathrm{m}^{-2} \mathrm{~d}^{-1}$ at $1000 \mathrm{~m}$ : these fluxes are at the lower end of the range of other data obtained in the North Atlantic Ocean, and are also fairly close to the estimates found at the Eumeli oligotrophic site [Morel, 1996; Bory et al., 2001]. Data from the drifting traps launched during the process study stations are consistent with the data of the moored sediment traps [Goutx et al., 2005]. These drifting trap data, as well as the mooring data [Guieu et al., 2005], show a shift from an export dominated by carbonate during $\mathrm{P} 1$ to an increased share of organic matter during P2 (more than half of the exported carbon at $200 \mathrm{~m}$, the carbonate representing still the major part at $400 \mathrm{~m}$ ) and of opal (although this flux is underestimated in the trap data). During P3, the fluxes are much lower (by a factor 4), with a very low contribution of biogenic silicate [Mosseri et al., 2005] and an equipartition of carbonate and organic carbon. These results are coherent with the time evolution of phytoplankton, presenting large concentrations of diatoms during P2, a larger contribution of coccolithophores during P1, and an oligotrophic situation during P3 (H. Claustre, personal communication, 2004; B. Quéguiner, personal communication, 2004).

[35] Net balances of oxygen and carbon variations show that the community biological activity in the POMME area results in a system which is strongly autotrophic during P1 and $\mathrm{P} 2$, and which changes into heterotrophic conditions in summer (P3) [Maixandeau et al., 2005]. Together with the role played by ocean dynamics and sea surface temperature (SST) variability, this biological production is responsible for an annual atmospheric $\mathrm{CO}_{2}$ uptake of the ocean [Gonzalez Davila et al., 2005]. The CARIOCA drifter data and the data from the surveys indicate a strong $\mathrm{CO}_{2}$ sink during $\mathrm{P} 1$ and $\mathrm{P} 2$, and a slight degassing during $\mathrm{P} 3$ (L. Merlivat, personal communication, 2003). Although the average flux is close to the flux obtained by Takahashi [Takahashi et al., 2002], the seasonal variation in the POMME region is much stronger during 2001, whereas in Takahashi et al.'s [2002] data compilation study the ocean is continuously taking up atmospheric $\mathrm{CO}_{2}$, all year round [Gonzalez Davila et al., 2005].

\subsubsection{Submeso- and Mesoscale Variability}

[36] Because of the temporal variability during the first leg surveys, an interpretation of the data collected solely in terms of spatial variability is difficult to do. Nevertheless, the mesoscale structures (eddies) and in particular the anticylonic eddies were rather stable: some of these structures were sampled during each cruise. This can be used for a first analysis of the seasonal evolution of the ecosystems within cyclonic and anticyclonic eddies, and of the differences between these structures. Preliminary numerical simulations show nevertheless that water mass exchanges between the eddies and the surrounding environment can be substantial over the several months separating successive surveys
(M. Lévy, personal communication, 2004). This indicates that eddies cannot be considered in isolation of their environment, in particular between P2 and P3.

[37] A preliminary analysis shows that the seasonal evolution within cyclonic (C4) and anticyclonic eddies (A1, A2) is quite similar. Nevertheless, when A2 is compared to $\mathrm{C} 4$ (Figure 2), it seems that the bloom (P1) as well as the transition toward oligotrophy (P2) occur sooner in the anticyclonic structure, characterized by a stronger and shallower stratification in A2 during winter. During summer (P3) the biological activity is stronger at the station located within the cyclone $\mathrm{C} 4$ than to its south, possibly because of the uplift of the isopycnal surfaces.

[38] Interestingly, the major signal in biological activity and tracer concentrations is obtained either within or close to the $\mathrm{A} 1$ anticyclone. On the basis of the float data, this eddy is extremely stable. It is characterized by very high levels of biomass and primary production, along with high diatom and biogenic silicate concentrations during $\mathrm{P} 2$, and large particle export during P1 and P2 (more than three times the export obtained at the other 2 day stations, although this statement should be considered with caution, as the position of these stations is not exactly localized at the very centre of the core, and as it might vary in time relatively to the structure). This anticyclone is clearly seen during the first leg of P3, as it is characterized by high nutrient levels [Fernández et al., 2005a] (around $6 \mu \mathrm{mol} \mathrm{kg} \mathrm{kg}^{-1}$ at $50 \mathrm{~m}$ compared to less than $1.5 \mu \mathrm{mol} \mathrm{kg} \mathrm{kg}^{-1}$ everywhere else) and by surface pigment concentrations much higher than elsewhere in the POMME area, associated with large dinoflagellates [Claustre et al., 2005]. This eddy was moreover always close to the NE sediment trap mooring, which shows also the largest particulate fluxes in the four moorings, with the largest proportion of $\mathrm{CaCO}_{3}$ export production and the smallest opal export, although diatom production is very large [Guieu et al., 2005]. Unfortunately, no long time series station could be occupied during the second leg of $\mathrm{P} 3$ for logistical reasons (emergency evacuation).

[39] The stations during the first legs barely resolved the mesoscale features. The interpretation of the data obtained during these surveys has to be moderated somewhat by the observations obtained from high-resolution surveys (Seasoar/OPCT, Tow-Yo), or high-frequency observations (Carioca buoys). These, yet unpublished observations as well as the modeling studies [Lévy et al., 2005b] suggest that the main variability in the biological variables is found at scales smaller than the mesoscale. At least in the late winter, these might be associated with fronts and eddy-eddy interactions, where ageostrophic processes, vertical velocities and spatial variability of mixed layer depth are expected to be important. These scales are also associated with strong horizontal currents. Keeping in mind the resolution issue during the first legs, this horizontal transport can be seen in the patterns of nutrient [Fernández et al., 2005a] or bacterial distributions [Thyssen et al., 2005], for instance within the northward current east of C4. Examples of submesoscale variability are shown in Figures $5-8$. Figure 5 is a SeaWiFS image obtained on 31 March with a $1 \mathrm{~km}$ horizontal resolution in the POMME area $(\mathrm{H}$. Loisel, personal communication, 2003): although some medium-scale features can be seen, most of the sea color gradients are associated 


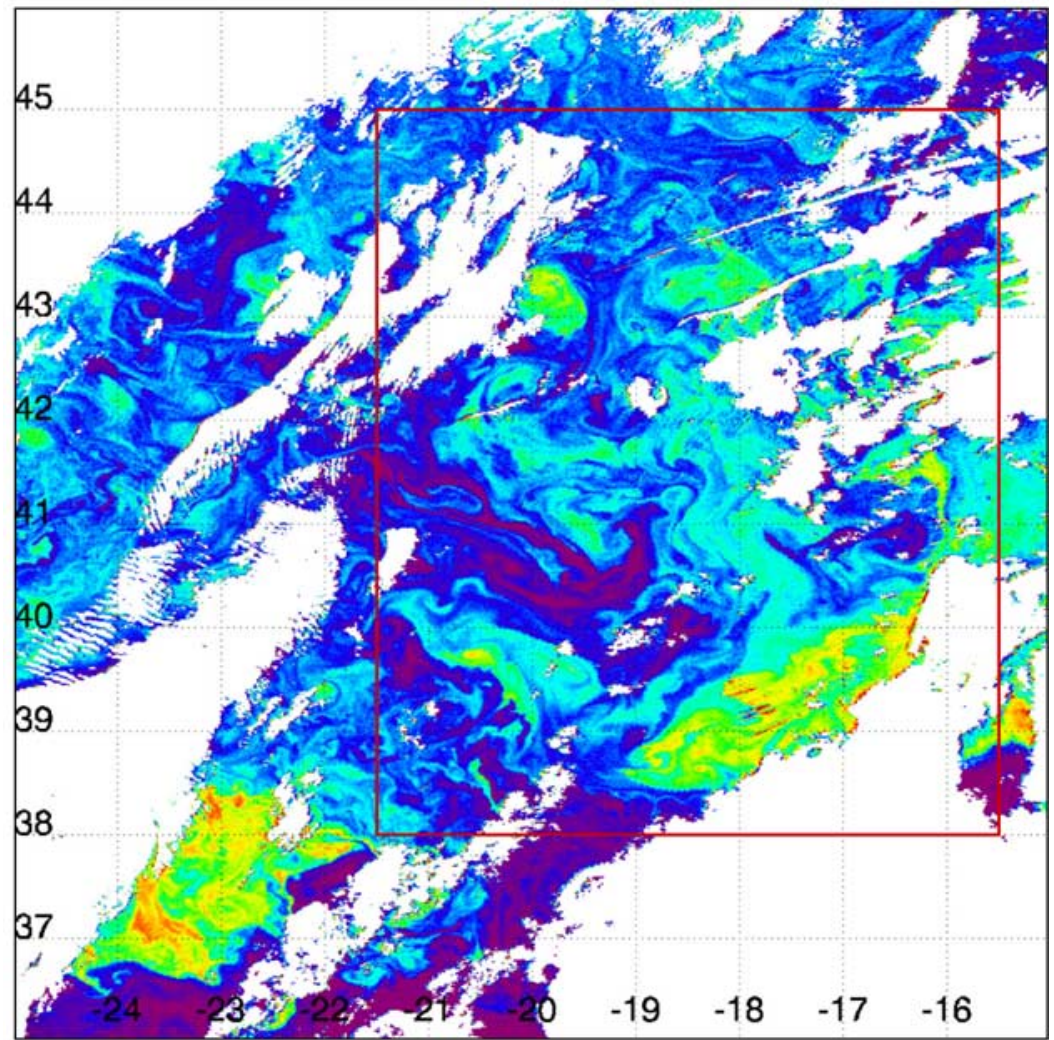

Figure 5. SeaWiFS image obtained on 31 March 2001, with a $1 \mathrm{~km}$ resolution. The cloudy areas are in white. Figure by H. Loisel (Université Lille, Lille, France).

with filaments. Figure 6 shows a Tow-Yo transect between the centers of the cyclonic patterns $\mathrm{C} 4$ and $\mathrm{C} 5 \mathrm{~B}$, crossing strong meridional fronts to the east of the anticyclones A1 and A4 (Figure 3) (L. Prieur, personal communication, 2003): a deep tongue of high oxygen concentration can be seen close to these fronts. This tends to show that ventilation and mode water formation could occur at small scales, e.g., through subduction associated with anticyclones. Figure 7 results from a Seasoar/OPCT survey during P3 between A4 and C4, along $42^{\circ} \mathrm{N}$. Maximum concentrations of zooplankton are obtained within small areas, possibly close to fronts (not shown): they can be associated with either maximum or minimum values of fluorescence. These observations indicate that whereas an increase of biomass might be strongly correlated with specific dynamical features at the submesoscale, the coupling between primary and secondary producers differs significantly from place to place, probably in relation to the intensity of ageostrophic vertical motions, the growth rate of phytoplankton and the grazing rate of zooplankton. Finally, Figure 8 shows the evolution of some parameters measured by a Carioca drifter during the bloom (L. Merlivat, personal communication, 2003). The fast variability of $\mathrm{pCO}_{2}$ corrected for the solubility (temperature) effect is strong (several tens of $\mu \mathrm{atm}$ in a few days), and can be partly explained by biological activity (biological pump), seen with the abrupt increase of fluorescence, but also by the impact of different water masses encountered by the drifter, possibly on both sides of the jet associated with a front.

\section{Conclusion}

[40] Although several difficulties were encountered during the field work, the sampling strategy could essentially be implemented as planned. Quasi-real time data analysis played a major role for choosing appropriate positions of the high-resolution sections and of the 2 day stations during the second legs. Obviously, the natural variability of the system, both in time (no synopticity of the first leg surveys), and in space (impact of partially sampled small scales difficult to ascertain over a large domain), complicate the interpretation of the data [Lévy et al., 2005b]. This is an important issue that will need to be addressed more thoroughly in future work associated with the POMME program. The preliminary results can be summarized by the following general statements.

[41] 1. Although the POMME area is supposed to be "quiescent" (e.g., associated with a low level of eddy turbulent kinetic energy), the observations showed that the meso- and small-scale activity was strongly developed and well organized.

[42] 2. Although the winter was rather warm, a deep winter mixed layer formed in the North of the zone. Moreover, part of the subduction of mode waters could be attributed to small scales, e.g., associated with the frontal 


\section{Density}

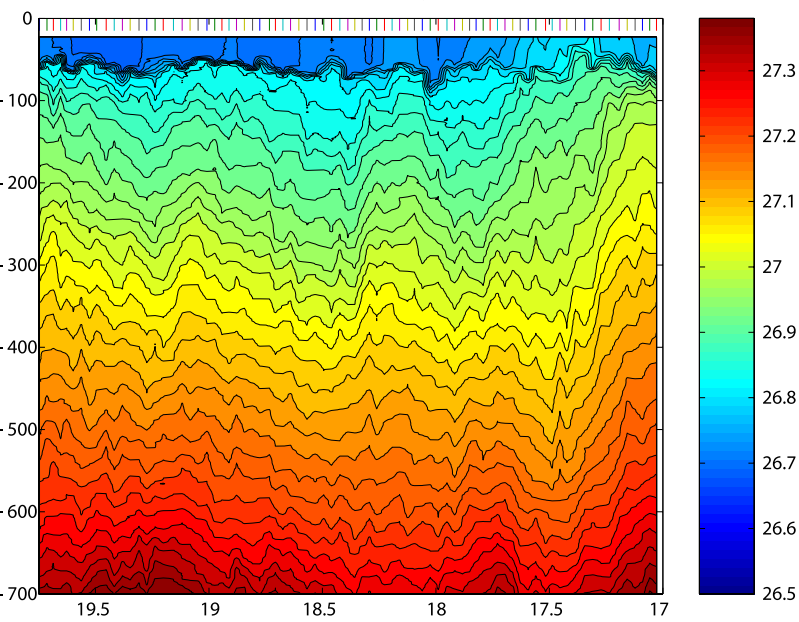

$0.2 \mathrm{~m} / \mathrm{s}$

$\mathrm{m}^{2} / \mathrm{s}$

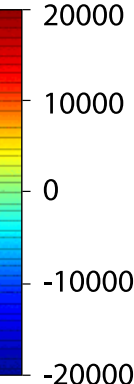

Fluorescence

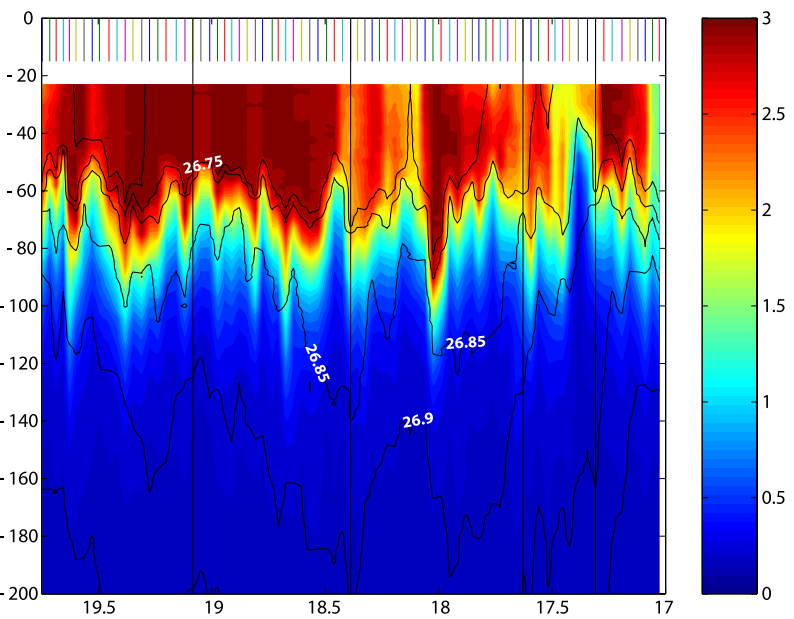

20000
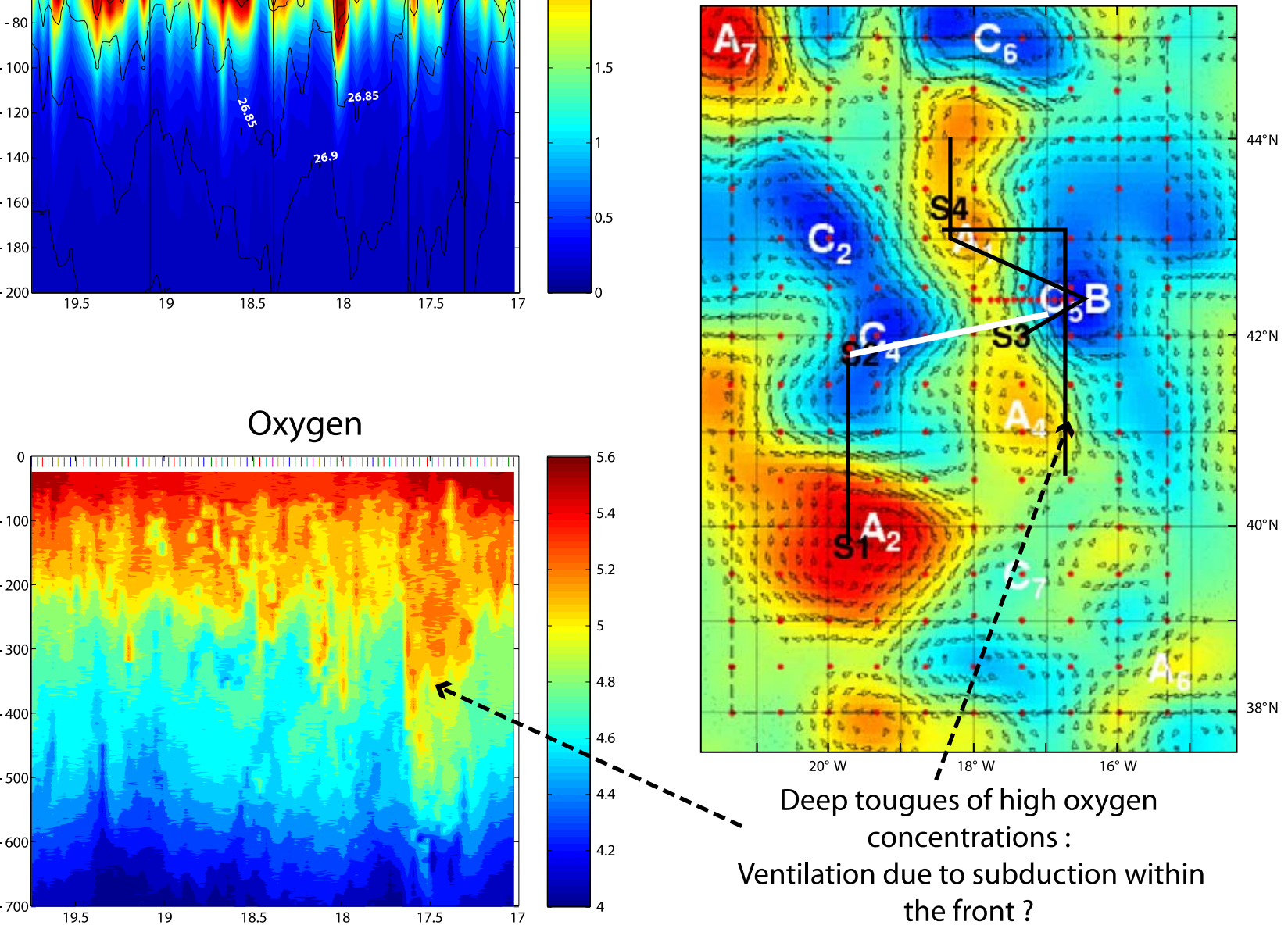

rowereson

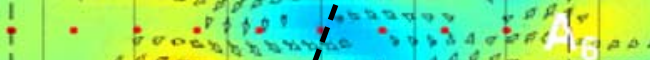

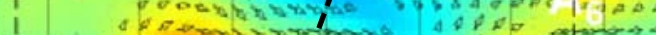

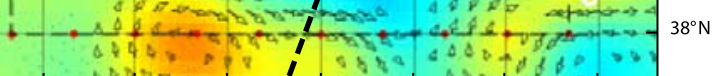

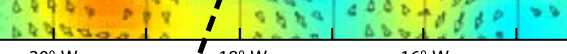

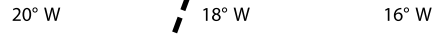

Deep tougues of high oxygen

concentrations :

Ventilation due to subduction within the front?

Figure 6. Tow-Yo section between the two cyclones $\mathrm{C} 4$ and C5B (white line on the figure on the right) during P2. (top) Density. (middle) Fluorescence. (bottom) Dissolved oxygen. Figure by L. Prieur (LOV, Villefranche-sur-mer, France). 

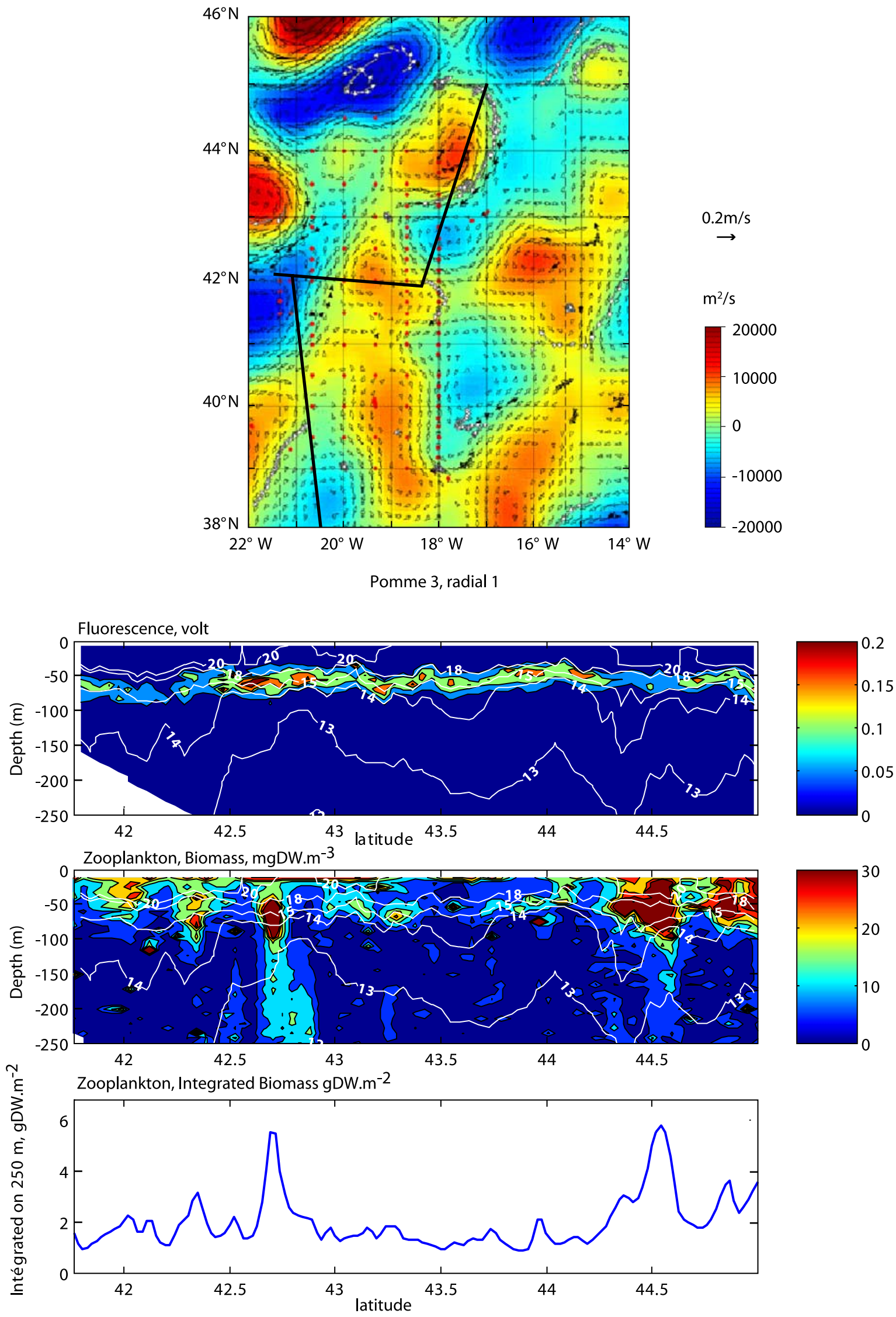

Figure 7. Seasoar/OPCT section during P3 across A1 to A4 (northern segment of the ship track). (top) Fluorescence from Seasoar (relative unit). (middle) Zooplankton biovolume from OPCT data. (bottom) Vertically integrated zooplankton biovolume. Figure by J.-P. Labat (LOV, Villefranche-sur-mer, France). 
(few kilometers) regions between individual mesoscale eddies.

[43] 3. There was a clear increase in primary production during $\mathrm{P} 1$ and $\mathrm{P} 2$, although the bloom was nevertheless not very intense. Levels of regenerated production were already rather high during P1, mostly in the south. While light was the main limiting term during winter [Blain et al., 2004], a strong Si-Fe colimitation was identified for diatom growth during February-April 2001, with a larger impact of the other macronutrients (mostly $\mathrm{N}$ ) during summer.

[44] 4. Cruise P3 was characterized by a very pronounced oligotrophic situation. Extremely weak biological activity as a consequence of depleted surface nutrients was associated with significant accumulation of dissolved organic matter.

[45] 5. The region can be sub divided within two production regimes [Lévy et al., 2005a]: north of the meandering front at around $41^{\circ} \mathrm{N}$, the POMME area is characterized by a subpolar regime, associated with a spring bloom driven by a sudden relieve from light limitation; south of $41^{\circ} \mathrm{N}$, the regime is a combination of a subtropical system, with a weak fall/winter bloom limited by nutrients, like in the subtropical gyre, followed by a "standard" spring bloom, like in the north. This intermediate regime can partly explain rather high production rates during $\mathrm{P} 1$, with low $f$ ratio.

[46] 6. The region is generally autotrophic (e.g., due to biological activity, dissolved $\mathrm{CO}_{2}$ is stored into organic carbon) during winter and spring, with a neutral tendency by the end of summer and early fall.

[47] 7. The ecosystem structure shows a strong seasonal variability (size of phytoplanktonic cells, food web,), as well as variability associated with small and medium scales.

[48] 8. The seasonal variability of the stocks and biogeochemical fluxes observed during the process study stations of the second legs is much more pronounced than the variability found between the different stations.

[49] 9. The POMME area is on average a net sink atmospheric $\mathrm{CO}_{2}$, the first estimates of air-sea exchanges being $0.37,0.45$ and $-0.0910^{12} \mathrm{gC} \mathrm{d}^{-1}$ (positive flux toward the ocean) respectively during P1, P2 and P3 for an area of $2.0310^{11} \mathrm{~m}^{2}$.

[50] The simultaneous availability of two vessels for several cruises within the same year allowed the sampling of many time- and space scales from several kilometers to several hundred kilometers, and from days to seasons. Moreover, this sampling schedule could be applied to many physical and biogeochemical parameters. This synoptic multiscale sampling is certainly one of the major and original achievements of this program, and it implies that resulting comprehensive data set will allow many more studies to still better describe and understand the processes at play at these different scales. To first order, the results show that none of these scales can be neglected, that is to say that they should all be taken into account when diagnosing rates of water mass formations or tracer transport. Although still of qualitative nature, one of the first conclusions of POMME deals with the importance of the small scales (several kilometers) for the biogeochemical characteristics of the water masses. This is associated with the frontal patterns and filaments which result from the dynamics of the eddies and of the mesoscale circulation. It is found that the differences in the structure and evolution of the marine ecosystem between the centers of cyclones and anticyclones are weaker than the differences found between the centre and the rim of the eddies and within fronts.

[51] In addition to the studies already under way that address the different components of the program, two important steps remain to be taken in order to complete the POMME program. At the present time, most of the data are available to the POMME community, but they must be validated and integrated into a database open to the whole scientific community. This should be achieved by mid 2005 . A further synthesis effort of this interdisciplinary project will be carried out by numerical simulations, embedding (a) biogeochemical model(s) (S. Roudesli, personal communication, 2004) into 3-D ocean circulation model(s) at high resolution [Paci et al., 2005; Lévy et al., 2005b]. This last step, which has already begun, will allow (1) to get a general and synoptic synthesis of the variability of the system; (2) to describe and quantify role of the different time- and space scales for the budgets of temperature, salt and tracer (for example, carbon) in the POMME area; (3) to carry out a detailed description and understanding of the major processes at play during subduction, bloom, and remineralization, and to explain the source, the transformation and the fate of water mass characteristics in the main thermocline; (4) to establish a local balance of the main physical and biogeochemical fluxes; and (5) to integrate the limited region sampled by POMME into a regionally larger framework (North Atlantic Ocean) in order to analyze the fate of the different tracers as they are isolated from atmospheric contact within the main thermocline for several years.

\footnotetext{
Figure 8. Carioca drifter observations. (top left) Drifter trajectory between day 49 (18 February) and 212 (1 July). The small numbers indicate the day associated with the position of the buoy. The letters $\mathrm{C}, \mathrm{A}$, and $\mathrm{F}$ indicate the approximate locations of cyclonic, anticyclonic, and frontal patterns. (top right) Time evolution of fluorescence (green) (relative units) and normalized dissolved inorganic carbon (DIC) $(\mathrm{red})(\mu \mathrm{mol} / \mathrm{kg})$. The large decrease in DIC observed at the end of March to the beginning of April is associated with a large increase of fluorescence, e.g., with the upset of a bloom. (bottom right) Time evolution of normalized DIC (red) $(\mu \mathrm{mol} / \mathrm{kg}$ ) and sea surface salinity (SSS) (black) (PSU). The DIC oscillations observed between day 140 and day 180 are strongly anticorrelated with SSS, which tends to show that this variability is mostly driven by the characteristics of the different water masses that the buoy crosses during its southward journey (see Figure 8 (top left)) within a meridional front. (bottom left) Air (black) and sea surface (red) $\mathrm{CO}_{2}$ partial pressure. When sea surface $\mathrm{pCO}_{2}$ is smaller (larger) than atmospheric $\mathrm{pCO}_{2}$, the ocean behaves like a $\mathrm{CO}_{2}$ sink (source), which is the case in winter and spring (in summer). Figure by L. Merlivat (LODYC, Paris).
} 


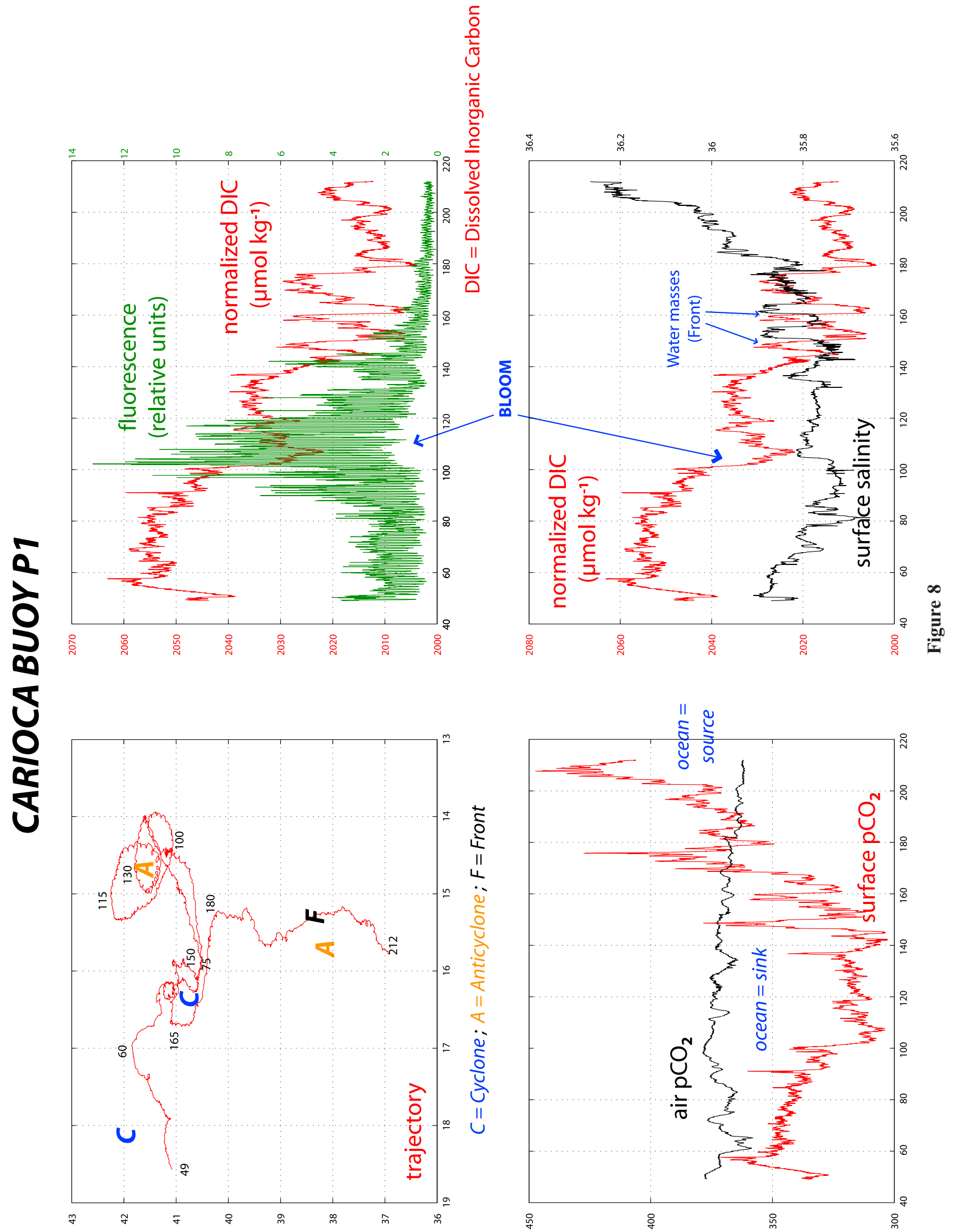




\section{References}

Assenbaum, M., and G. Reverdin (2005), Near real-time analyses of the mesoscale circulation during the POMME experiment, Deep Sea Res., Part I, 52, 1345-1373.

Blain, S., C. Guieu, H. Claustre, K. Leblanc, T. Moutin, B. Quéguiner, J. Ras, and G. Sarthou (2004), Availability of iron for phytoplankton in the north-east Atlantic Ocean, Limnol. Oceanogr., 49, 2095-2104.

Bory, A., et al. (2001), Downward particle fluxes within different productivity regimes off the Mauritanian upwelling wone (EUMELI program), Deep Sea Res., Part I, 48, 2251-2282

Bourras, D., G. Reverdin, H. Giordani, and G. Caniaux (2004), Response of the atmospheric boundary layer to a mesoscale oceanic eddy in the northeast Atlantic, J. Geophys. Res., 109, D18114, doi:10.1029/ 2004JD004799.

Bouruet-Aubertot, P., H. Mercier, F. Gaillard, and P. Lherminier (2005), Evidence of strong inertia-gravity wave activity during the POMME experiment, J. Geophys. Res., 110, C07S06, doi:10.1029/2004JC002747.

Brügge, B. (1995), Near-surface mean circulation and kinetic energy in the central North Atlantic from drifter data, J. Geophys. Res., 100, 20,54320,554 .

Caniaux, G., A. Brut, D. Bourras, H. Giordani, A. Paci, L. Prieur, and G. Reverdin (2005a), A 1 year sea surface heat budget in the northeastern Atlantic basin during the POMME experiment: 1. Flux estimates, J. Geophys. Res., 110, C07S02, doi:10.1029/2004JC002596.

Caniaux, G., S. Belamari, H. Giordani, A. Paci, L. Prieur, and G. Reverdin (2005b), A 1 year sea surface heat budget in the northeastern Atlantic basin during the POMME experiment: 2. Flux optimization, J. Geophys. Res., 110, C07S03, doi:10.1029/2004JC002695.

Claustre, H., M. Babin, D. Merien, J. Ras, L. Prieur, S. Dallot, O. Prasil, H. Dousova, and T. Moutin (2005), Toward a taxon-specific parameterization of bio-optical models of primary production: A case study in the North Atlantic, J. Geophys. Res., 110, C07S12, doi:10.1029/ 2004JC002634.

Cunningham, S. A. (2000), Circulation and volume flux of the North Atlantic using synoptic hydrographic data in a Bernouilli inverse, J. Mar. Res., 58, 1-35.

Dam, H. G., C. A. Miller, and S. H. Jonasdottir (1993), The trophic role of mesozooplankton at $47^{\circ} \mathrm{N}, 20^{\circ} \mathrm{W}$ during the North Atlantic Bloom Experiment, Deep Sea Res., Part II, 40, 197-212.

de Boyer Montégut, C., G. Madec, A. S. Fischer, A. Lazar, and D. Iudicone (2004), Mixed layer depth over the global ocean: An examination of profile data and a profile-based climatology, J. Geophys. Res., 109, C12003, doi:10.1029/2004JC002378.

Ducklow, H. W., and R. P. Harris (1993), Introduction to the JGOFS North Atlantic Bloom Experiment, Deep Sea Res., Part II, 40, 1-8.

Fernández, C. I., P. Raimbault, G. Caniaux, N. Garcia, and P. Rimmelin (2005a), Influence of mesoscale eddies on nitrate distribution during the POMME program in the northeast Atlantic Ocean, J. Mar. Syst., 55, $155-175$.

Fernández, C. I., P. Raimbault, N. Garcia, P. Rimmelin, and G. Caniaux (2005b), An estimation of annual new production and carbon fluxes in the northeast Atlantic Ocean during 2001, J. Geophys. Res., 110, C07S13, doi:10.1029/2004JC002616.

Gaillard, F., H. Mercier, and C. Kermabon (2005), A synthesis of the POMME physical data set: One year monitoring of the upper layer J. Geophys. Res., 110, C07S07, doi:10.1029/2004JC002764.

Giordani, H., G. Caniaux, L. Prieur, A. Paci, and S. Giraud (2005), A 1 year mesoscale simulation in the northeast Atlantic: Mixed layer heat and detrainment-entrainment budgets during the POMME experiment, J. Geophys. Res., 110, C07S08, doi:10.1029/2004JC002765.

Gonzalez Davila, M., J. M. Santana Casiano, L. Merlivat, L. Barbero, and E. V. Dafner (2005), Fluxes of $\mathrm{CO}_{2}$ between the atmosphere and ocean during the POMME project in the northeast Atlantic Ocean, J. Geophys. Res., 110, C07S11, doi:10.1029/2004JC002763.

Goutx, M., C. Guigue, N. Leblond, A. Desnues, A. Dufour, D. Aritio, and C. Guieu (2005), Particle flux in the northeast Atlantic Ocean during the POMME experiment (2001): Results from mass, carbon, nitrogen, and lipid biomarkers from the drifting sediment traps, J. Geophys. Res., 110, C07S20, doi:10.1029/2004JC002749.

Guieu, C., M. Roy-Barman, N. Leblond, C. Jeandel, M. Souhaut, B. Le Cann, A. Dufour, and C. Bournot (2005), Vertical particle flux in the northeast Atlantic Ocean (POMME experiment), J. Geophys. Res., 110, C07S18, doi:10.1029/2004JC002672.

Hazeleger, W., and S. S. Drijfhout (2000), Eddy subduction in a model of the subtropical gyre, J. Phys. Oceanogr., 30, 677-695.

Jickells, T. D., P. P. Newton, P. King, R. S. Lampitt, and C. Boutle (1996), A comparison of sediment trap records of particle fluxes from 19 to $48^{\circ} \mathrm{N}$ in the northeast Atlantic and their relation to surface water productivity, Deep Sea Res., Part II, 43, 971-986.
Karayanni, H., U. Christaki, F. Van Wambeke, M. Denis, and T. Moutin (2005), Influence of ciliated protozoa and heterotrophic nanoflagellates on the fate of primary production in the northeast Atlantic Ocean, J. Geophys. Res., 110, C07S15, doi:10.1029/2004JC002602.

Karrasch, B., H. G. Hoppe, S. Ullrich, and S. Podewski (1996), The role of mesoscale hydrography on microbial dynamics in the northeast Atlantic: Results of a spring bloom experiment, J. Mar Res., 54, 99-122.

Leach, H., S. J. Bowerman, and M. E. McCulloch (2002), Upperocean eddy transports of heat, potential vorticity, and volume in the northeastern North Atlantic-"Vivaldi 1991,"J. Phys. Oceanogr., 32, 2926-2937.

Leblanc, K., A. Leynaert, I. C. Fernandez, P. Rimmelin, T. Moutin, P. Raimbault, J. Ras, and B. Quéguiner (2005), A seasonal study of diatom dynamics in the North Atlantic during the POMME experiment (2001): Evidence for Si limitation of the spring bloom, J. Geophys. Res., 110, C07S14, doi:10.1029/2004JC002621.

Le Cann, B., M. Assenbaum, J.-C. Gascard, and G. Reverdin (2005), Observed mean and mesoscale upper ocean circulation in the midlatitude northeast Atlantic, J. Geophys. Res., 110, C07S05, doi:10.1029/ 2004JC002768.

Lévy, M., L. Mémery, and G. Madec (2000), Combined effects of mesoscale processes and atmospheric high-frequency variability on the spring bloom in the MEDOC area, Deep Sea Res., Part I, 47, 27-53.

Lévy, M., Y. Lehahn, J.-M. André, L. Mémery, H. Loisel, and E. Heifetz (2005a), Production regimes in the northeast Atlantic: A study based on Sea-viewing Wide Field-of-view Sensor chlorophyll and ocean general circulation model mixed layer depth, J. Geophys. Res., 110, C07S10, doi:10.1029/2004JC002771.

Lévy, M., M. Gavart, L. Mémery, G. Caniaux, and A. Paci (2005b), A fourdimensional mesoscale map of the spring bloom in the northeast Atlantic (POMME experiment): Results of a prognostic model, J. Geophys. Res., 110, C07S21, doi:10.1029/2004JC002588.

Lochte, K., and O. Pfannkuche (1987), Cyclonic cold-core eddy in the eastern North Atlantic. I I., Nutrients, phytoplankton and bacterioplankton, Mar. Ecol. Prog. Ser., 39, 153-164.

Longhurst, A. (1993), Seasonal cooling and blooming in tropical oceans, Deep Sea Res., Part I, 40, 2145-2165.

Mahadevan, A., M. Lévy, and L. Mémery (2004), Mesoscale variability of sea surface $\mathrm{pCO}_{2}$ : What does it respond to?, Global Biogeochem. Cycles, 18, GB1017, doi:10.1029/2003GB002102.

Maixandeau, A., D. Lefèvre, C. Fernandez, R. Sempéré, R. Fukuda-Sohrin, J. Ras, F. Van Wambeke, G. Caniaux, and B. Quéguiner (2005), Mesoscale and seasonal variability of community production and respiration in the NE Atlantic Ocean, Deep Sea Res., Part I, in press.

McCartney, M. S. (1982), The subtropical recirculation of Mode Waters, J. Mar. Res., 40, Suppl., 427-464.

McGillicuddy, D. J., Jr., A. R. Robinson, and J. J. McCarthy (1995), Coupled physical and biological modelling of the spring bloom in the North Atlantic (II): Three dimensional bloom and post-bloom processes, Deep Sea Res., Part X, 42, 1359-1398.

Morel, A. (1996), An ocean flux study in eutrophic, mesotrophic and oligotrophic situations: The EUMELI program, Deep Sea Res., Part I, 43, $1185-1190$.

Mosseri, J., B. Quéguiner, P. Rimmelin, N. Leblond, and C. Guieu (2005), Sea fluxes in the northeast Atlantic frontal zone of Mode Water formation $\left(38^{\circ}-45^{\circ} \mathrm{N}, 16^{\circ}-22^{\circ} \mathrm{W}\right)$ in $2001-2002, J$. Geophys. Res., 110, C07S19, doi: $10.1029 / 2004 J C 002615$.

Niiler, P. P., A. S. Sybrandy, K. Bi, P. M. Poulain, and D. Bitterman (1995), Measurements of the water-following capability of holey-sock and TRISTAR drifters, Deep Sea Res., Part I, 42, 1951-1964.

Nurser, A. J. G., and J. W. Zhang (2000), Eddy-induced mixed layer shallowing and mixed layer/thermocline exchange, J. Geophys. Res., 105, $21,851-21,868$.

Oschlies, A., and V. Garçon (1998), Eddy induced enhancement of primary production in a model of the North Atlantic Ocean, Nature, 394, 266269.

Paci, A., G. Caniaux, M. Gavart, H. Giordani, M. Lévy, L. Prieur, and G. Reverdin (2005), A high-resolution simulation of the ocean during the POMME experiment: Simulation results and comparison with observations, J. Geophys. Res., 110, C07S09, doi:10.1029/2004JC002712.

Paillet, J., and M. Arhan (1996), Oceanic ventilation in the eastern North Atlantic, J. Phys. Oceanogr., 26, 2036-2052.

Paillet, J., and H. Mercier (1997), An inverse model of the eastern North Atlantic general circulation and thermocline ventilation, Deep Sea Res., Part I, 44, 1293-1328.

Pingree, R. D., and B. Le Cann (1992), Three anticyclonic slope water oceanic eddied (swoddies) in the southern Bay of Biscay in 1990, Deep Sea Res., Part I, 39, 1147-1175.

Pollard, R. T., M. J. Griffiths, S. A. Cunningham, J. F. Read, F. F. Pérez, and A. F. Rios (1996), Vivaldi 1991 - A study of the formation, circula- 
tion and ventilation of Eastern North Atlantic Central Water, Prog. Oceanogr., 37, 167-192.

Reverdin, G., M. Assenbaum, and L. Prieur (2005), Eastern North Atlantic Mode Waters during POMME (September 2000-2001), J. Geophys. Res., 110, C07S04, doi:10.1029/2004JC002613.

Rios, A. F., F. F. Pérez, and F. Fraga (1992), Water masses in the upper and middle North Atlantic Ocean east of the Azores, Deep Sea Res., Part A. $39,645-658$

Sohrin, R., and R. Sempéré (2005), Seasonal variation in total organic carbon in the northeast Atlantic in 2000-2001, J. Geophys. Res., doi:10.1029/2004JC002731, in press.

Spall, S. A., and K. J. Richards (2000), A numerical model of mesoscale frontal instabilities and plankton dynamics: I. Model formulation and initial experiments, Deep Sea Res., Part I, 47, 1261-1301.

Spall, M. A., R. A. Weller, and P. W. Furey (2000), Modeling the threedimensional upper ocean heat budget and subduction rate during the Subduction Experiment, J. Geophys. Res., 105, 26,151-26,166.

Takahashi, T., T. T. Takahashi, and S. C. Sutherland (1995), An assessment of the role of the North Atlantic as a $\mathrm{CO}_{2}$ sink, Philos. Trans. R. Soc. London, Ser. B, 348, 143-152.

Takahashi, T., et al. (2002), Global sea-air $\mathrm{CO}_{2}$ flux based on climatological surface ocean $\mathrm{pCO}_{2}$ and seasonal biological and temperature effects, Deep Sea Res., Part II, 49, 1601-1622.

Thyssen, M., D. Lefèvre, G. Caniaux, J. Ras, C. Fernández, and M. Denis (2005), Spatial distribution of heterotrophic bacteria in the northeast Atlantic (POMME study area in spring 2001), J. Geophys. Res., 110, C07S16, doi:10.1029/2004JC002670.

Valdivieso da Costa, M., H. Mercier, and A. M. Tréguier (2005), Effects of the mixed-layer time variability on kinematic subduction rate diagnostics, J. Phys. Oceanogr., in press.
Weller, R. A., P. W. Furey, M. A. Spall, and R. E. Davis (2004), The largescale context for oceanic subduction in the northeast Atlantic, Deep Sea Res., Part I, 51, 665-699.

Wroblewski, J. S., J. L. Sarmiento, and G. R. Flierl (1988), An ocean-basinscale model of plankton dynamics in the North Atlantic: 1. Solutions for the climatological oceanographic conditions in May, Global Biogeochem. Cycles, 2, 199-218

Yoder, J. A., J. Aiken, R. N. Swift, F. E. Hoge, and P. M. Stegman (1993), Spatial variability in near-surface chlorophyll a fluorescence measured by the Airborne Oceanographic Lidar (AOL), Deep Sea Res., Part II, 40, $37-53$.

L. Mémery, Laboratoire des Sciences de l'Environnement Marin, Institut Universitaire Européen de la Mer, Centre National de Recherche Scientifique/Université Bretagne Occidentale, Technopôle Brest Iroise, F-29280 Plouzané, France. (memery@lodyc.jussieu.fr)

A. Oschlies, School of Ocean and Earth Science, Southampton Oceanography Centre, University of Southampton, SO14 3ZH Southampton, U.K. (andreas.oschlies@soc.soton.ac.uk)

J. Paillet, Service Hydrologique et Océanographique de la Marine, BP 30316, F-29603 Brest, France. (paillet@shom.fr)

G. Reverdin, Laboratoire d'Océanographie et du Climat, Expérimentations et Approches Numériques, Institut Pierre-Simon Laplace, Centre National de Recherche Scientifique/Institut de Recherche pour le Développment/Université Pierre et Marie Curie, Case 100, 4 Place Jussieu, F-75265 Paris Cedex 5, France. (reverdin@lodyc.jussieu.fr) 